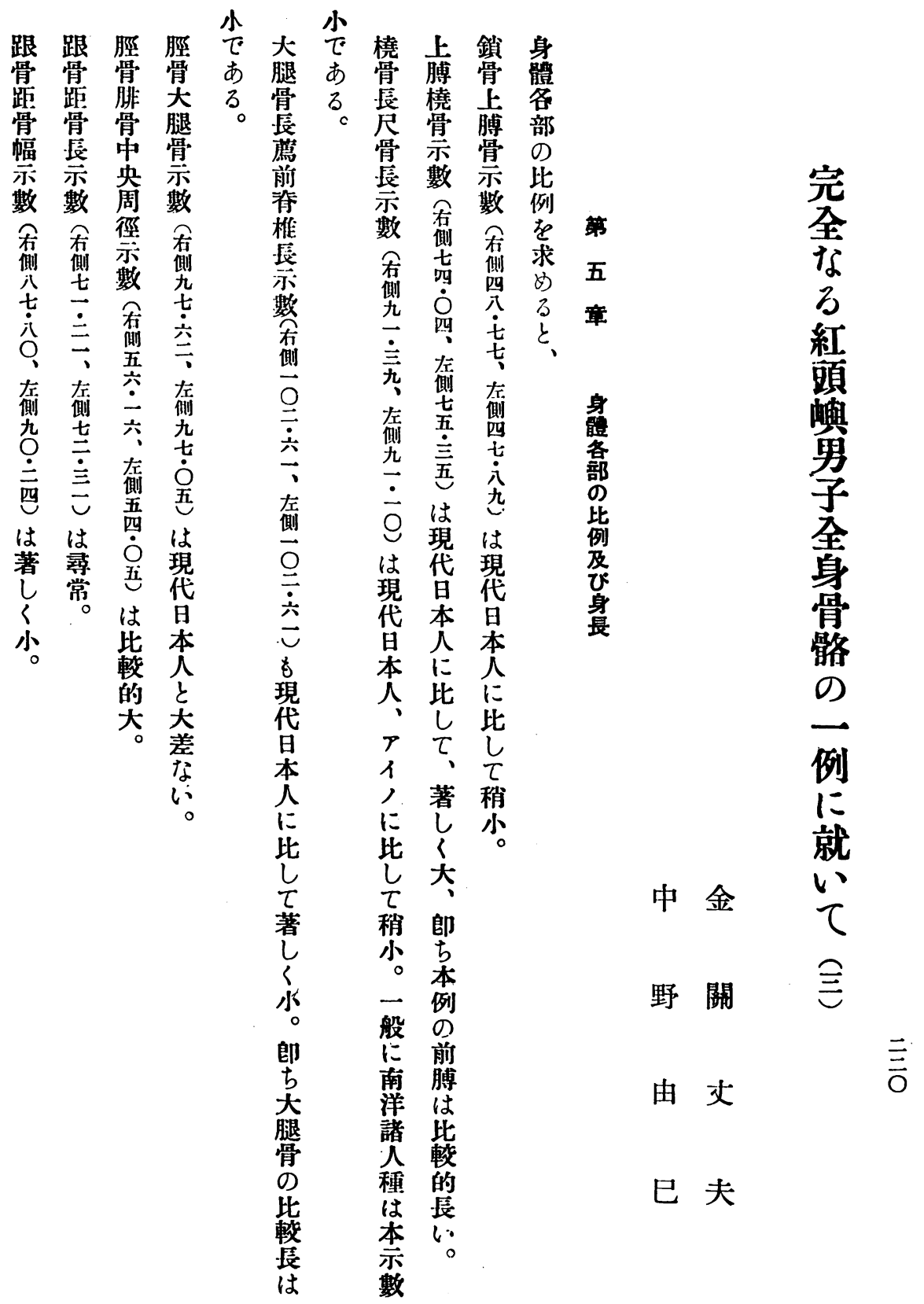


リー高

卡は本以

れ气骨的

ブ骨較は完

緛

な橈们頭全

特梋大蓋な

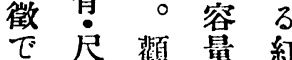

学

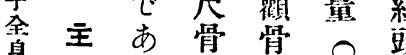

骨要方犬は

骼

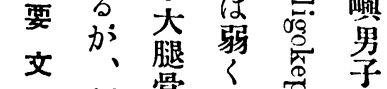

關 献 腰骨々 总悬

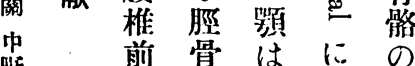

西吉突傾一

の べ檙き例

著 $\tau 、 、$

し 扇 眼 頭 就

以本笨形心

點 著ははて

やし 低宁の

笉人认总觀

骨、。造 测

の 前 眼

彎 膊樔总絬

㤟宁間导果

の腿距气重

な 點は蜜要

ば 肯

比大あにの

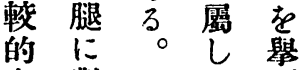

高 對、雤

等 ᄂ . 前 $る$

の $\tau$ 頭

性牀較部次

三 奘 較

人放に

$\tau$

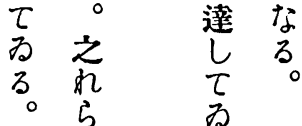

は

稍

わ

顏

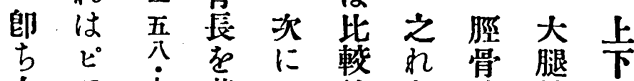

之? 基

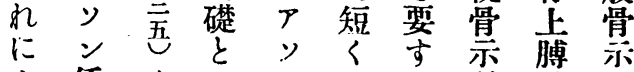

よ係はせ产るる數骨數

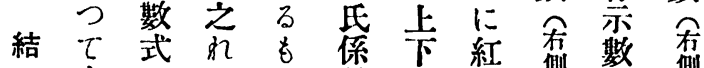

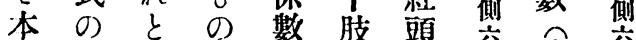
人規伯气武策突㤑公

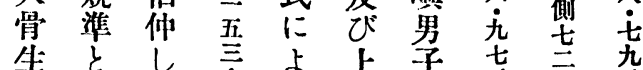
特

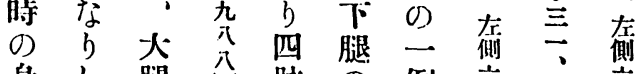
身し腿忘肢の例公公公

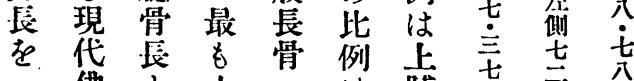

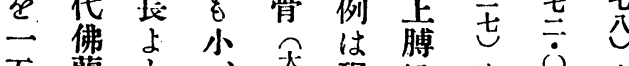

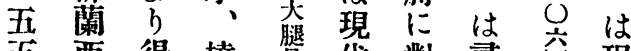
五西得橈賉䒫對尋公現 六人た骨占是し常は代

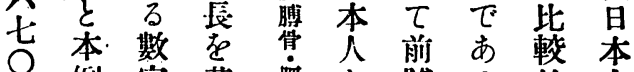

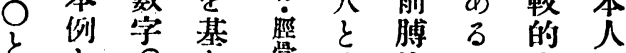

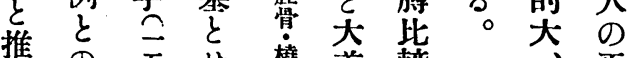
定の吾世楚差較 平 定各茾当骨的即均

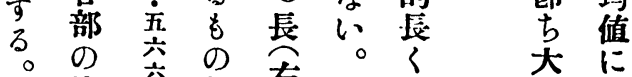

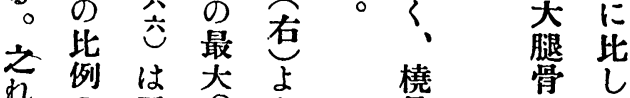

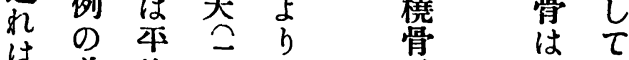
は美均五生長比極 等萑值 爷時 公 度語吾忩身吉短僅

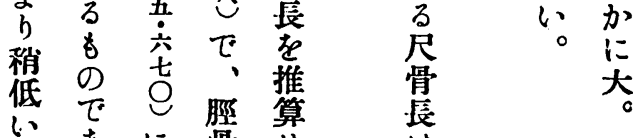
方手昷世

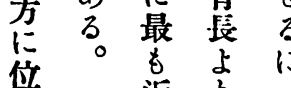

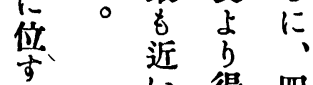
は 毞 的 心得四骨大 即 3 中

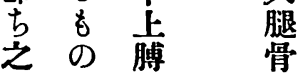




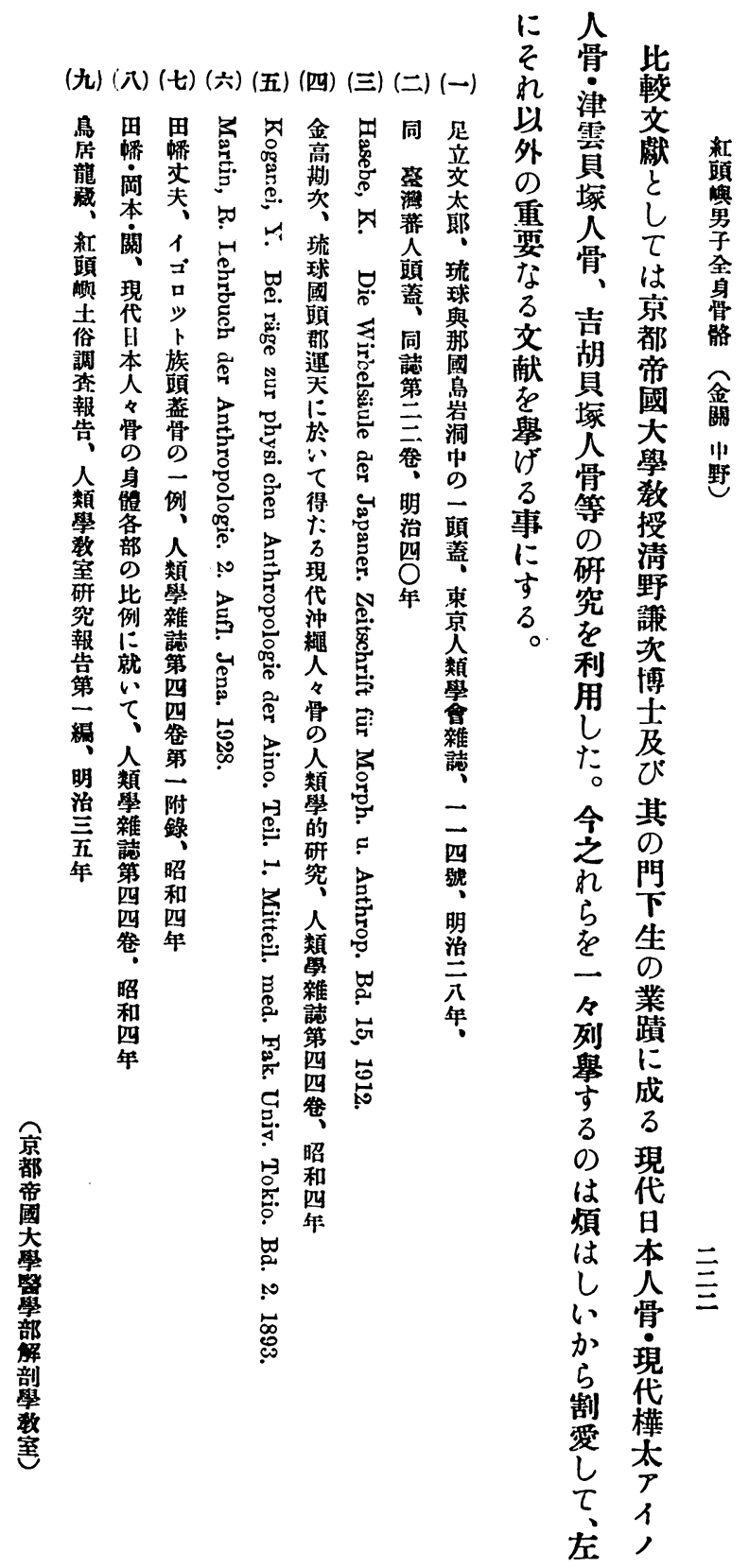




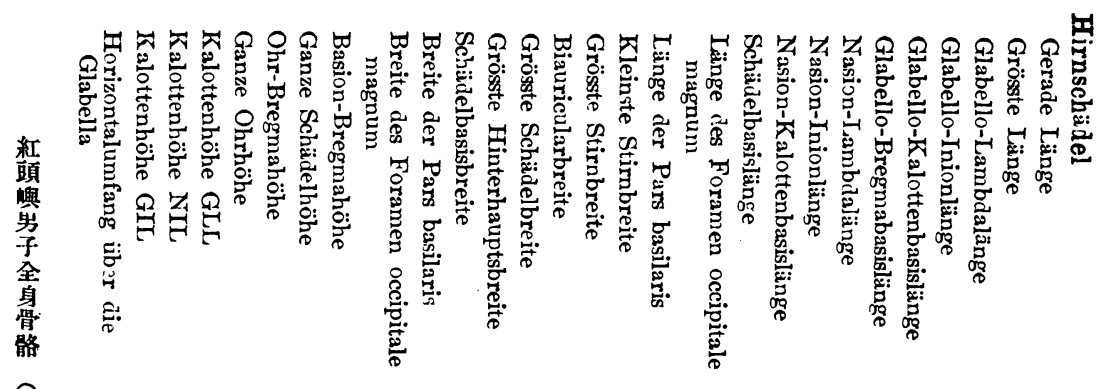

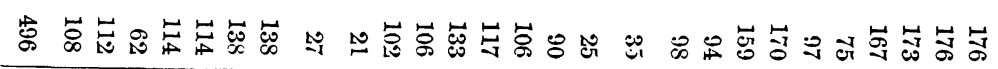

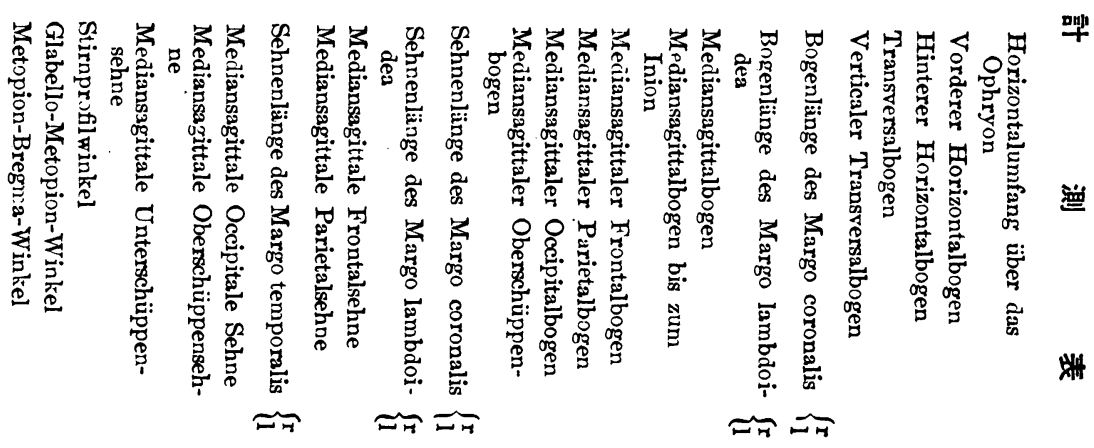

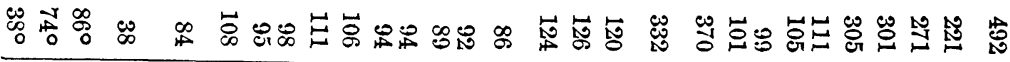

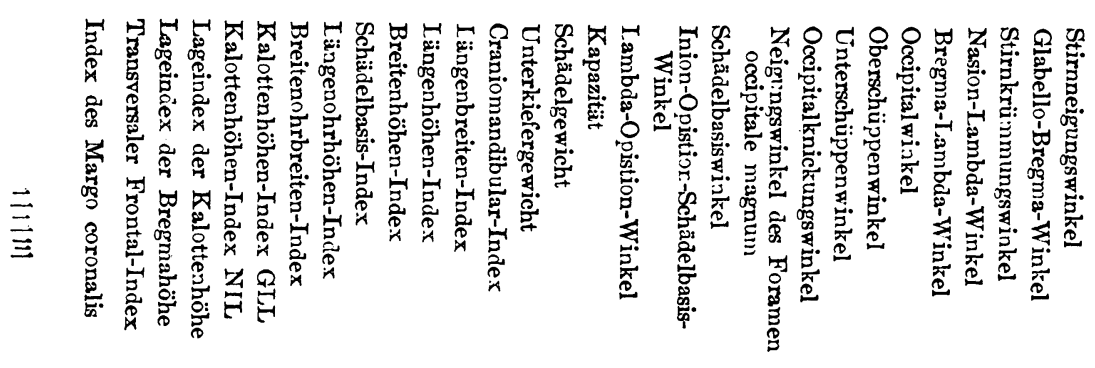

$=$

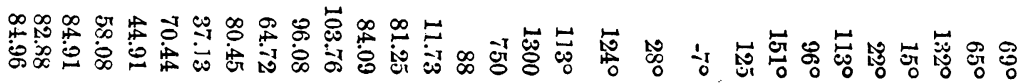




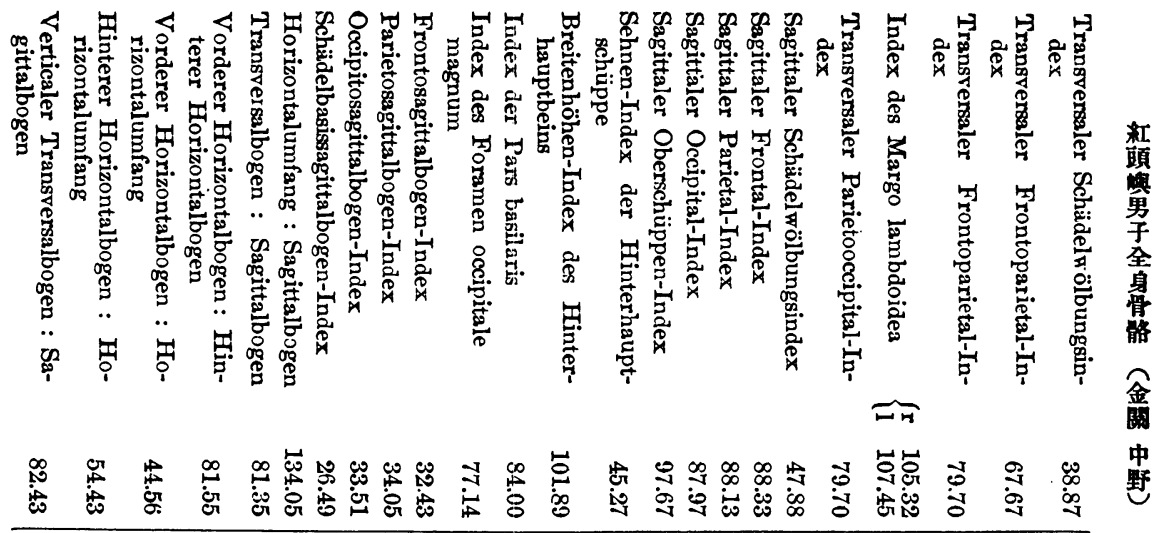

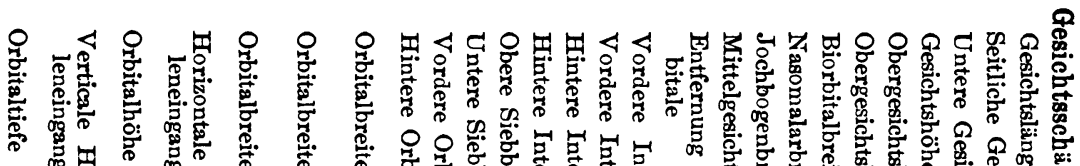

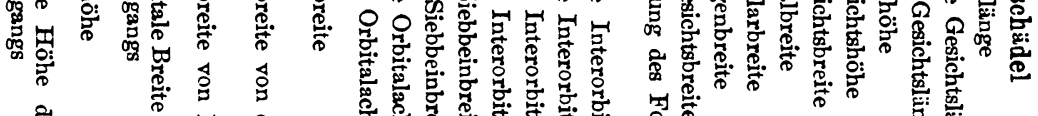

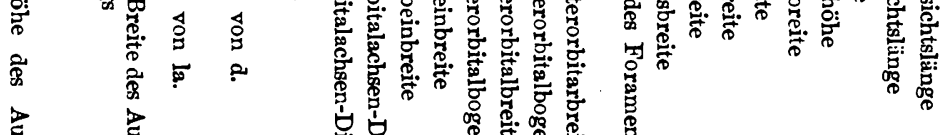

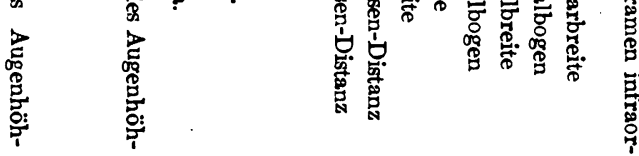

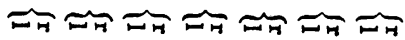

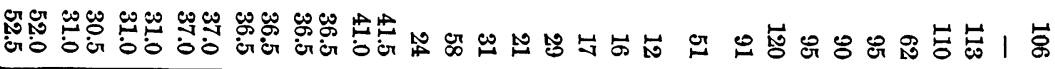

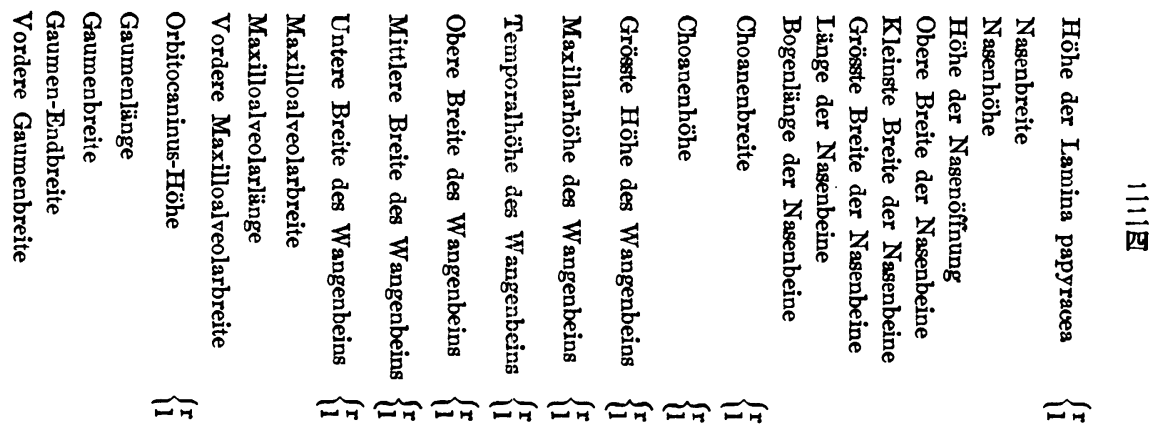

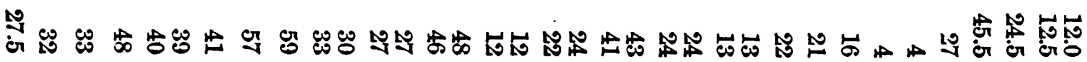




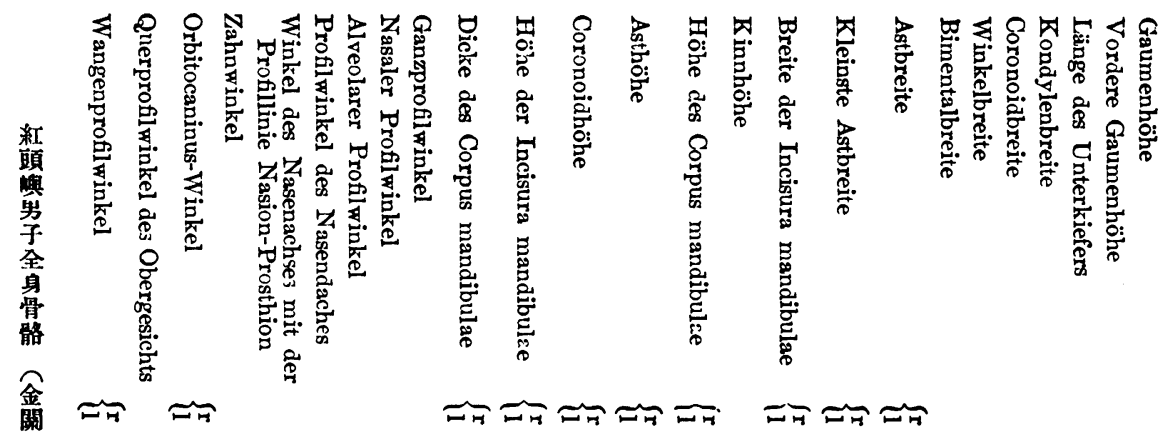

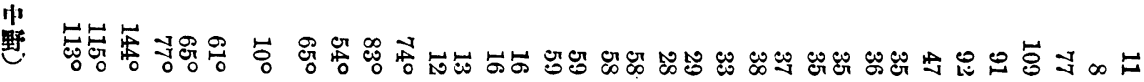

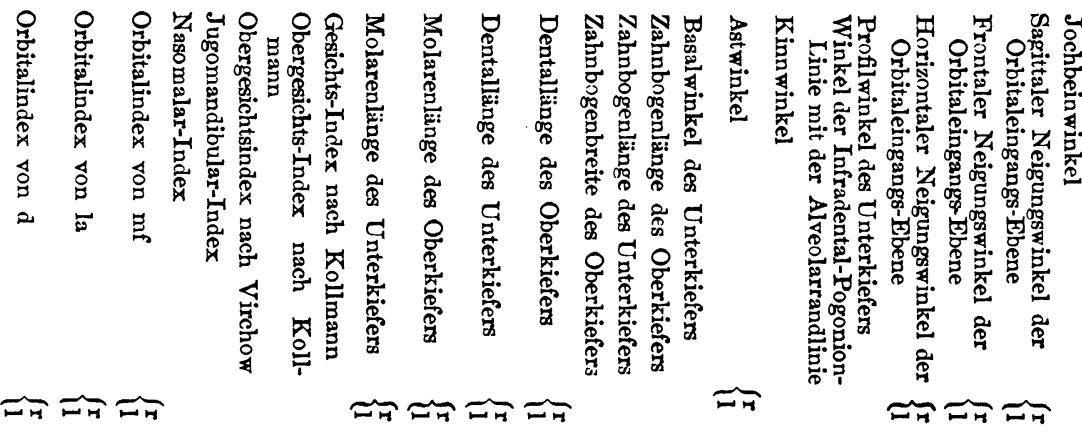

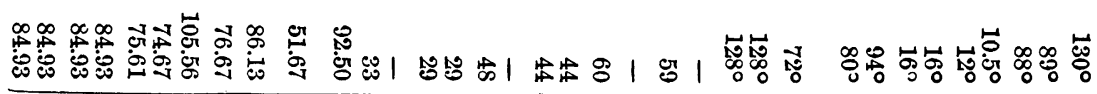

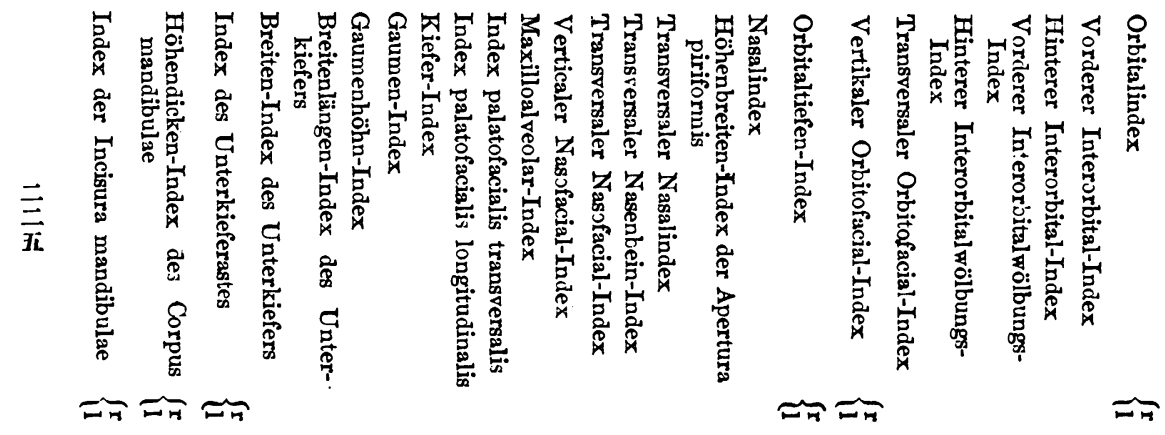

我出

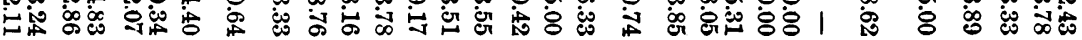



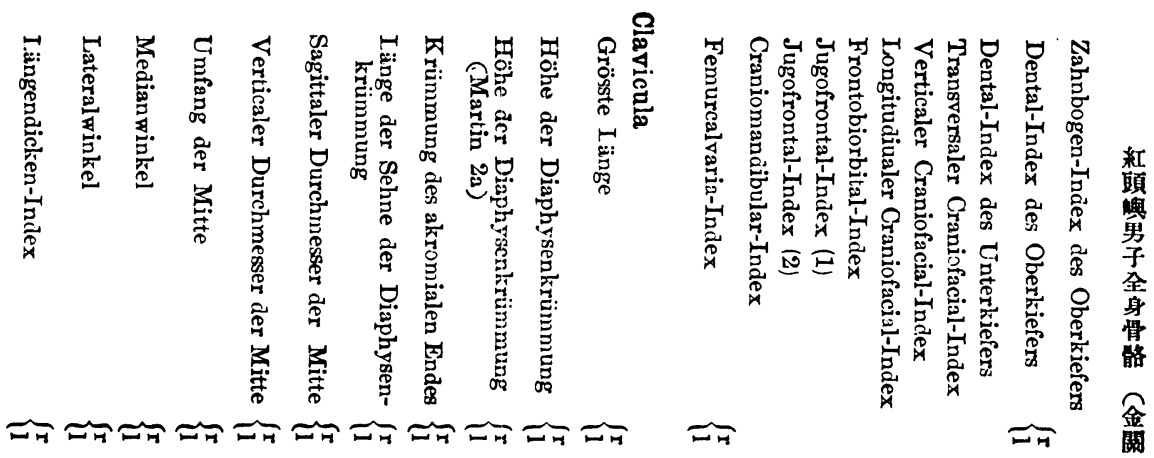

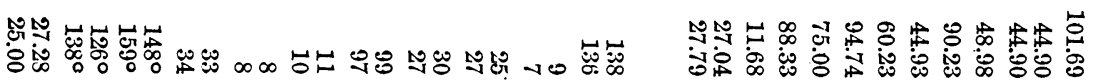

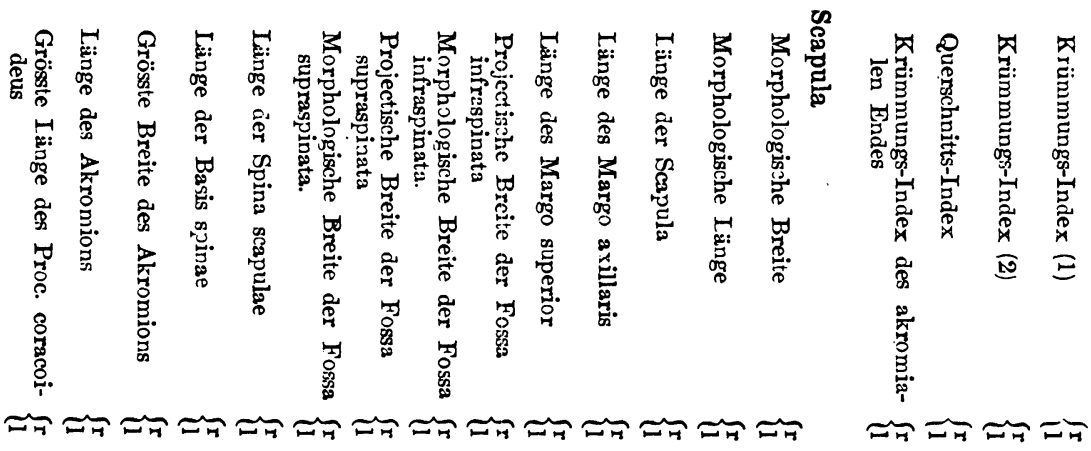

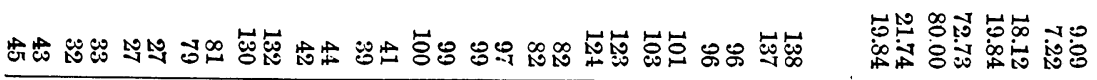

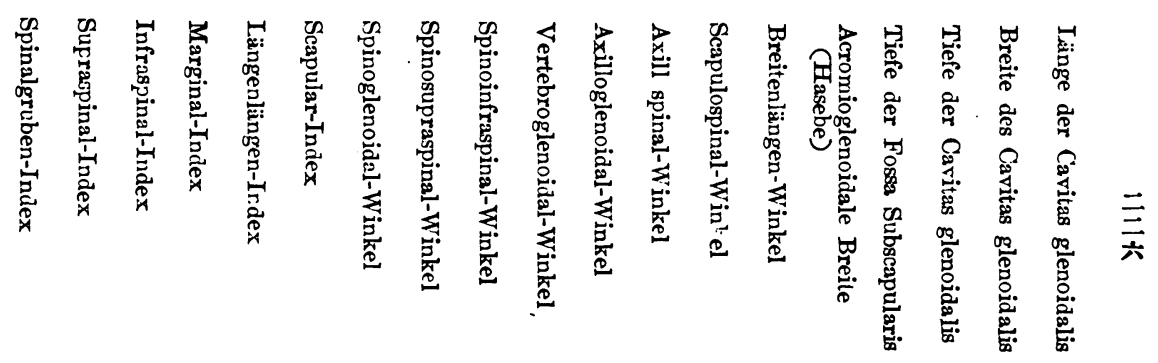

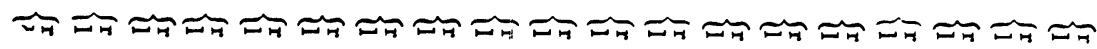

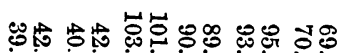

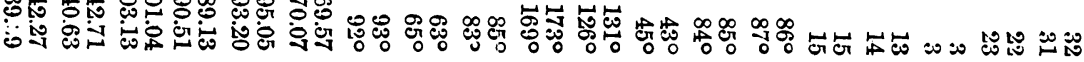




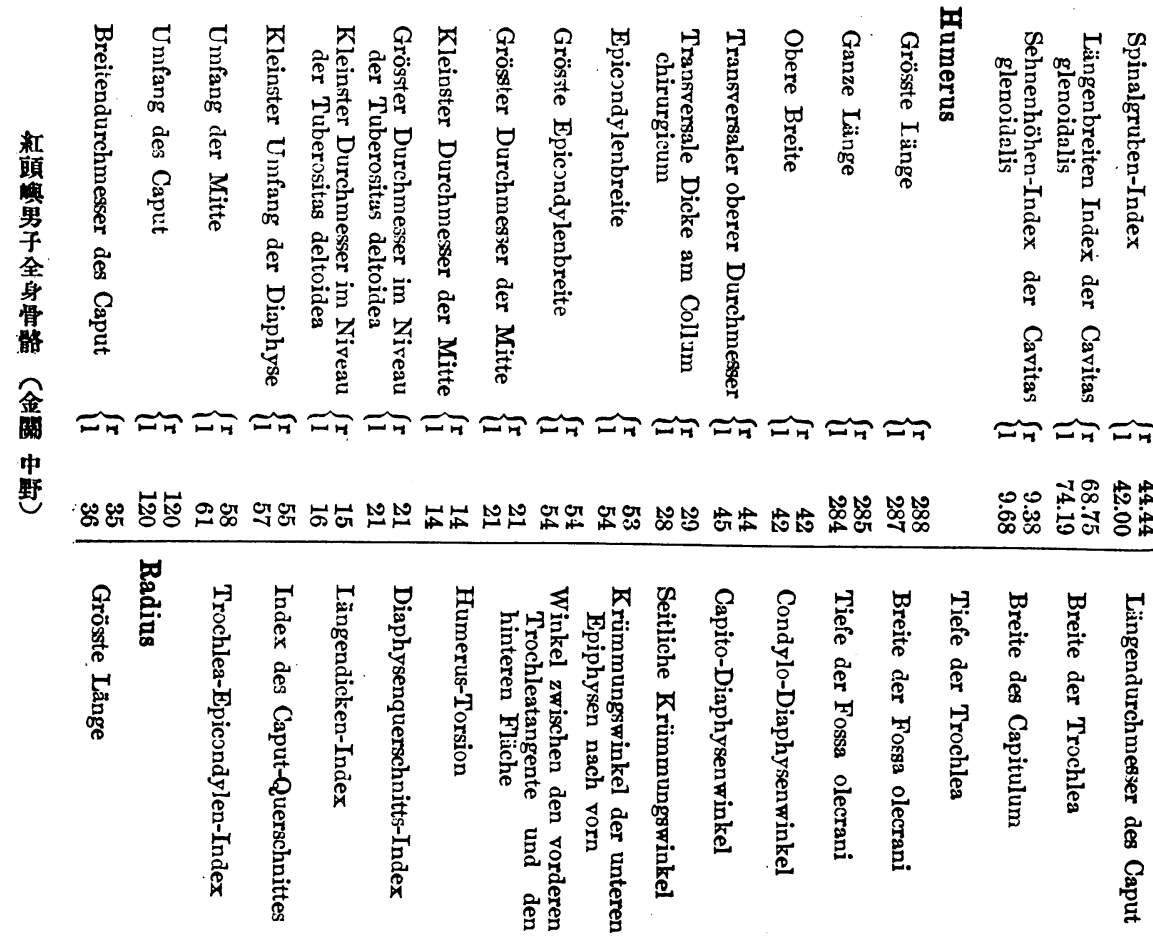

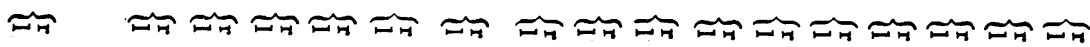

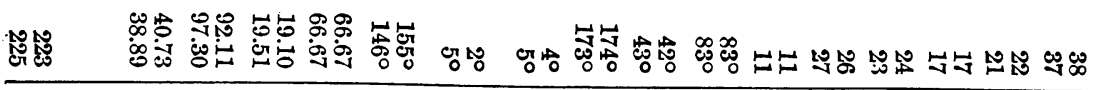

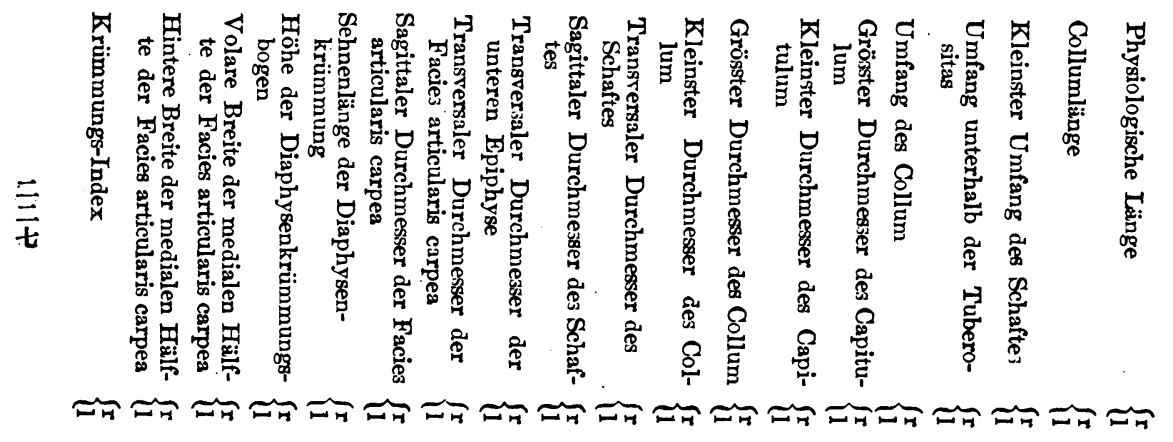

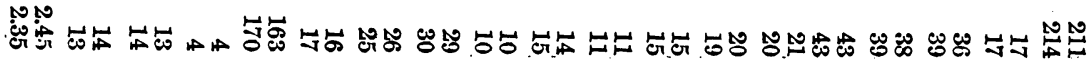




\section{人類學雜䩩 45.6}

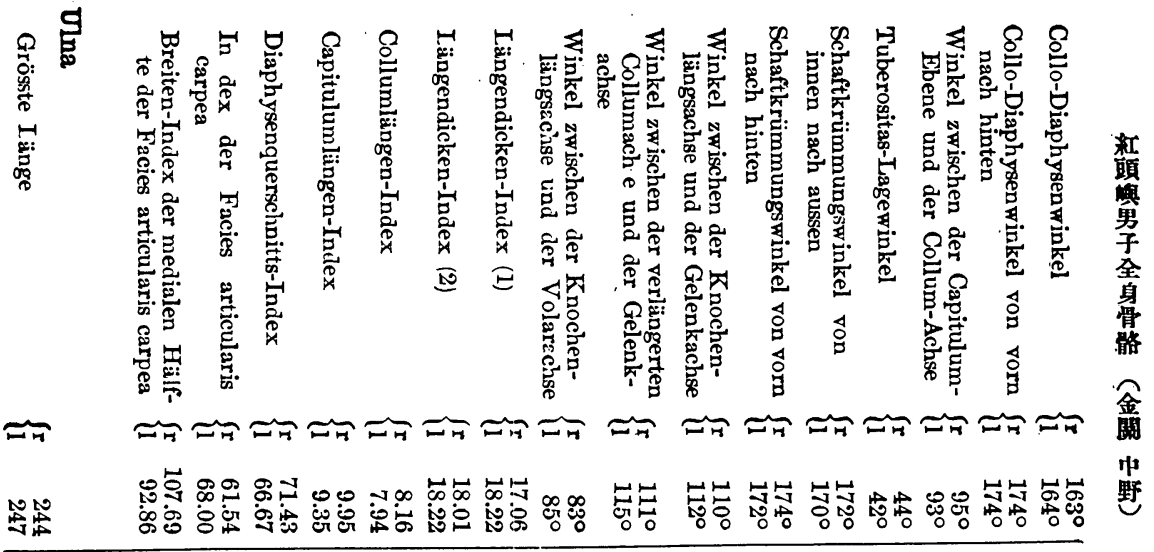

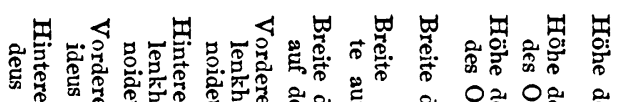

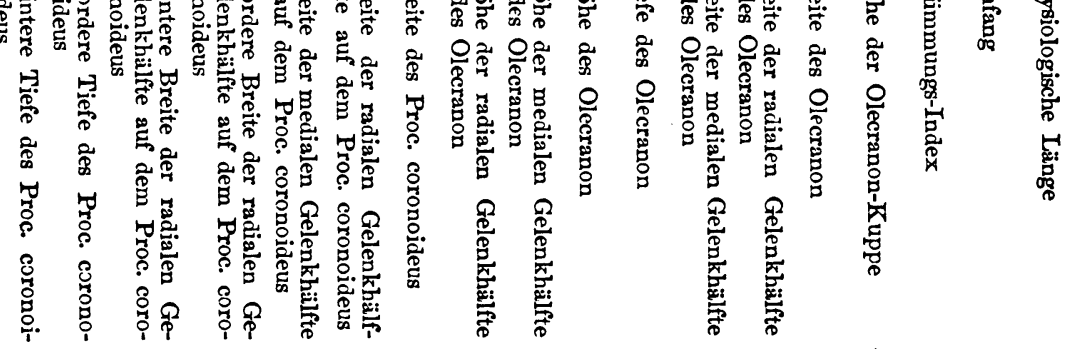

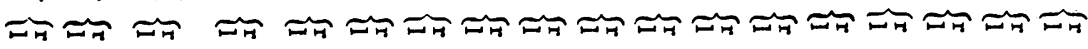

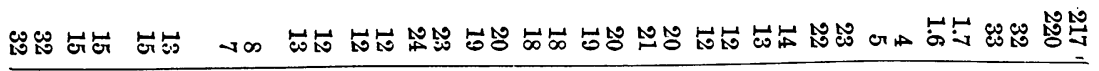

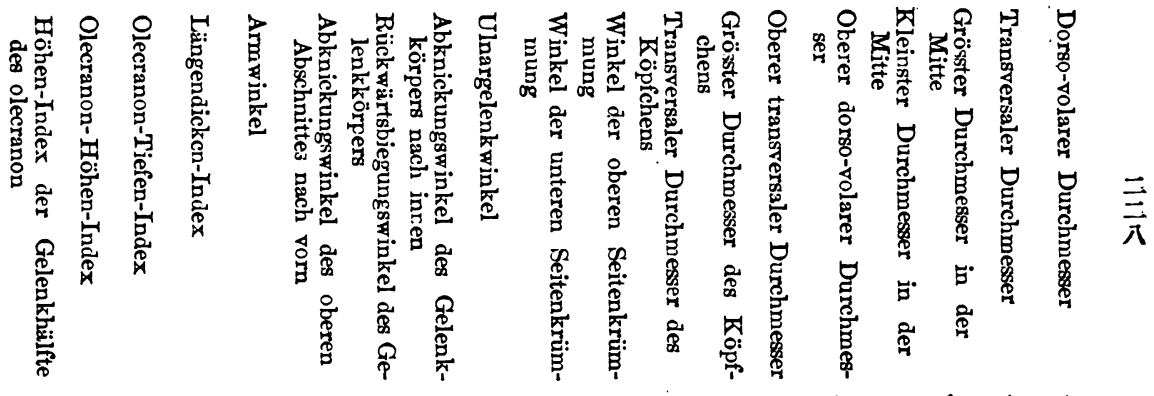

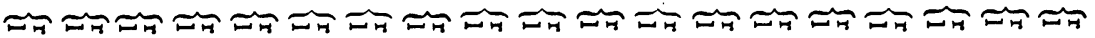

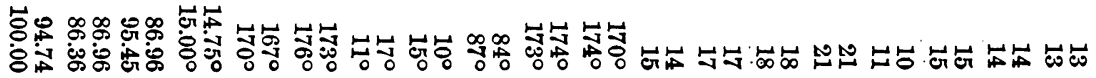



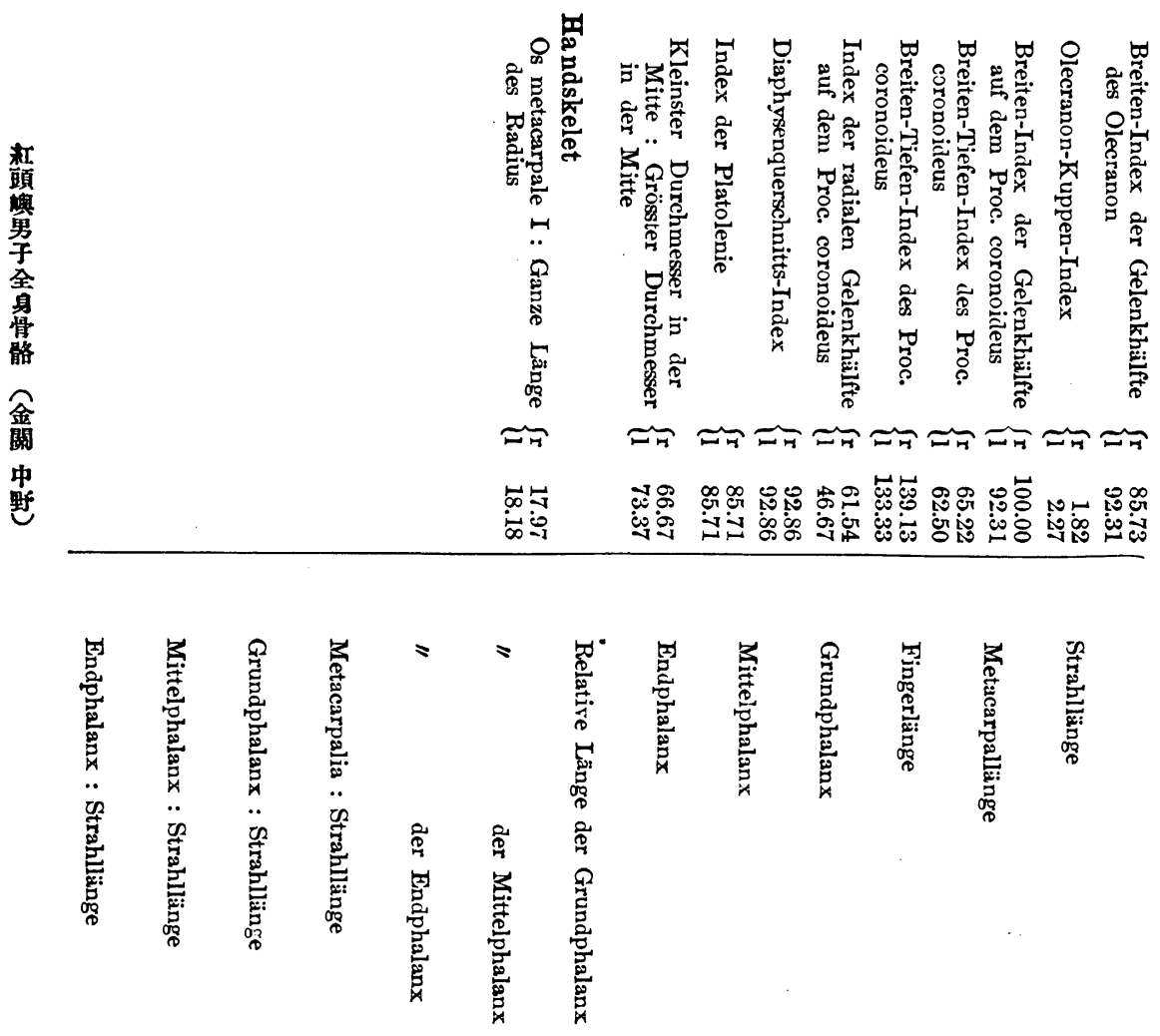

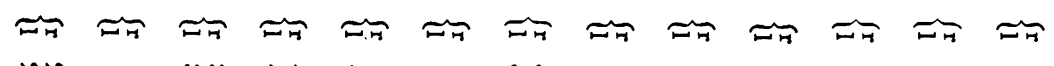

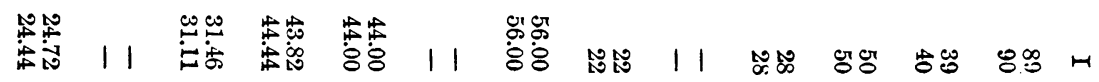

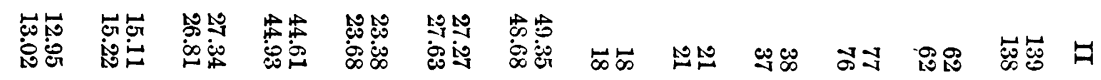
无

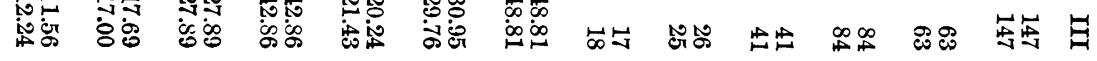

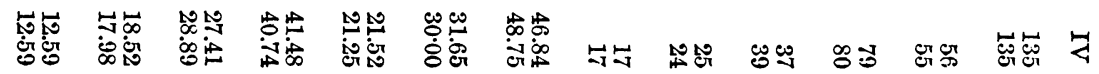

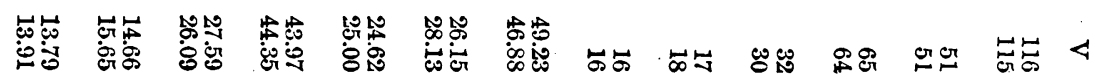




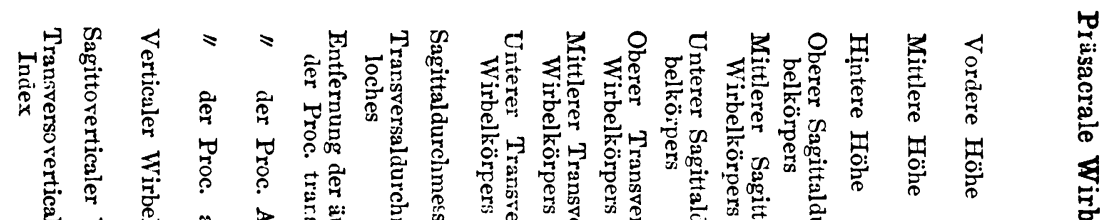

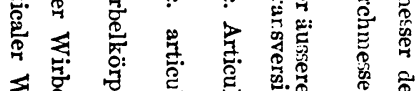

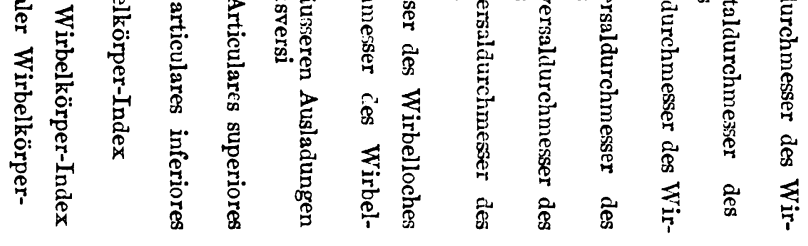

is

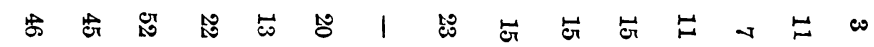

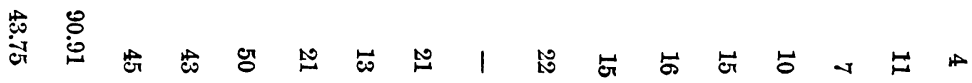
or

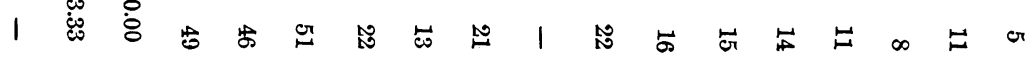

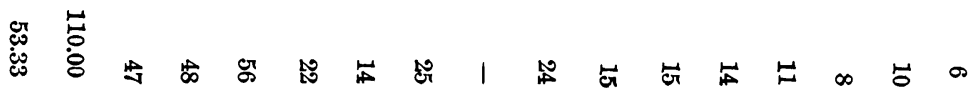

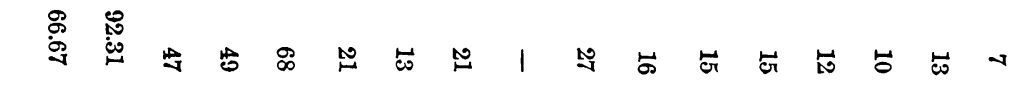

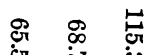

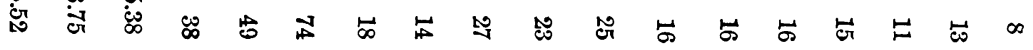

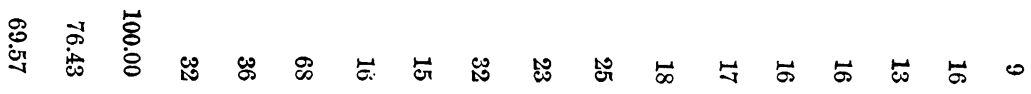

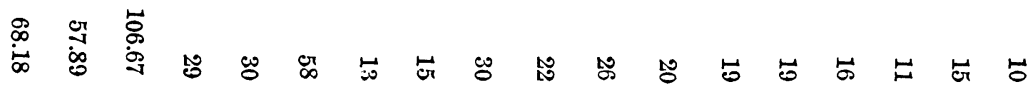

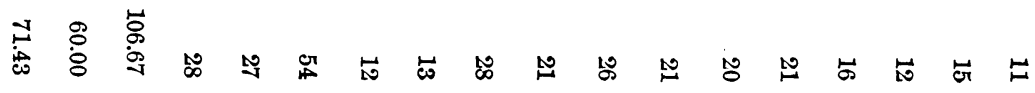
玄

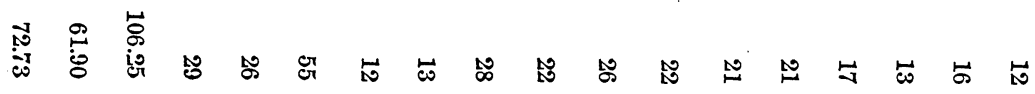
空 
昭和 5 年 6 月

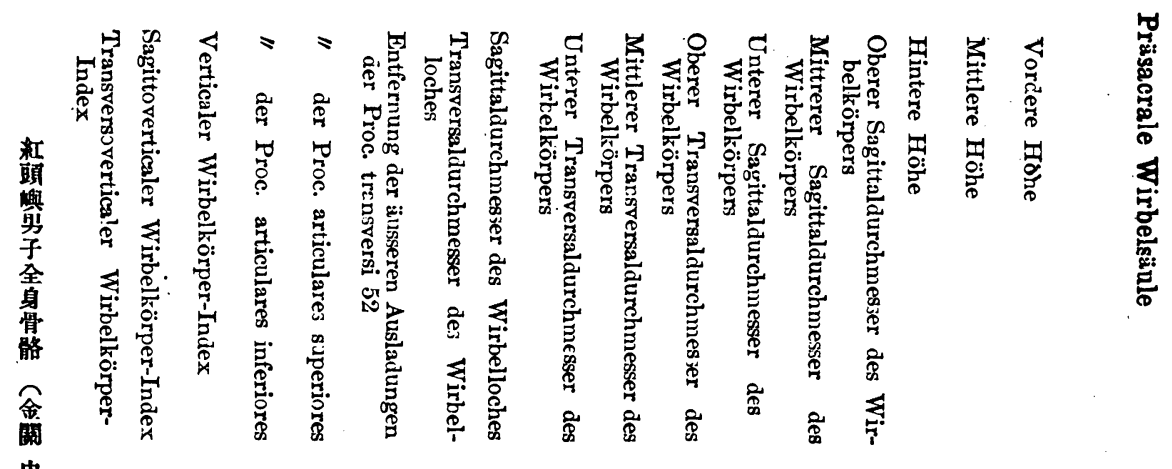

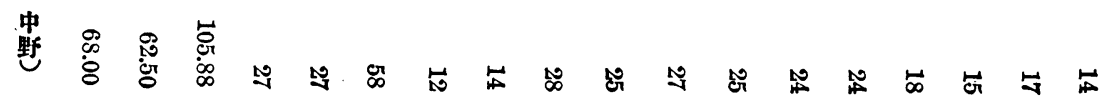

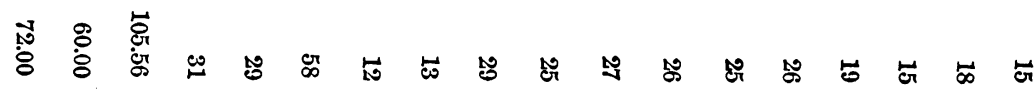
牙

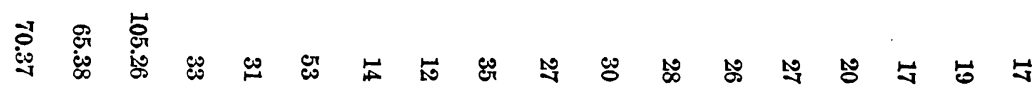
兽

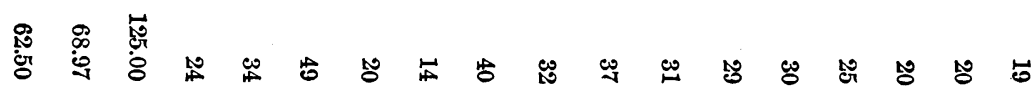

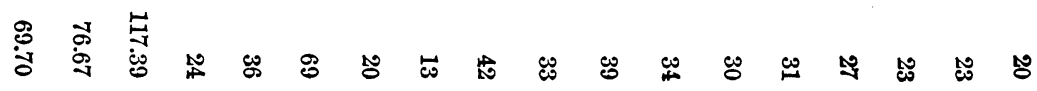

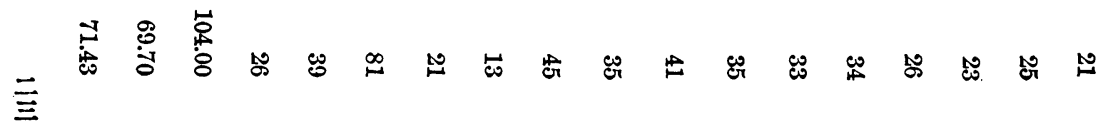

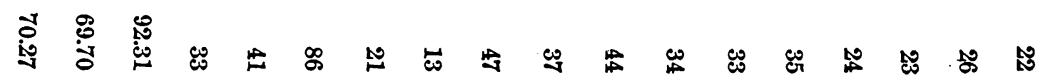

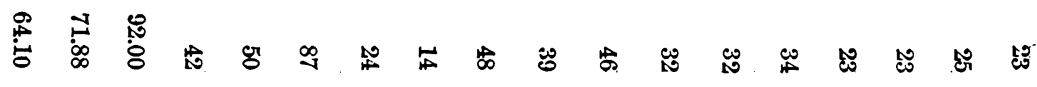

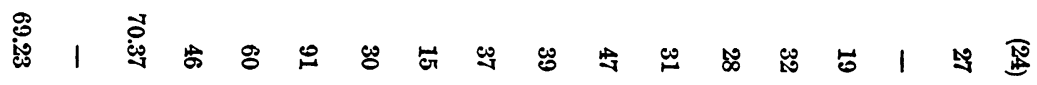




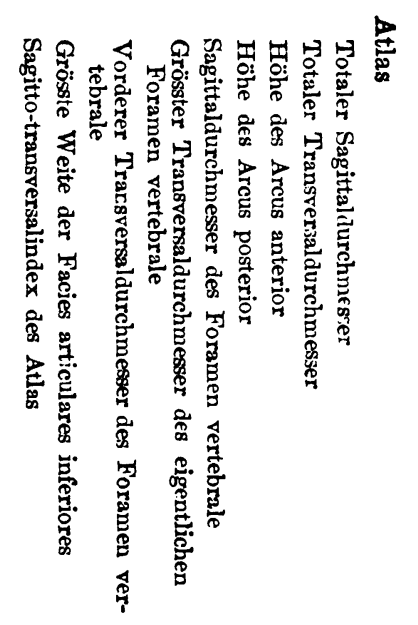

焉出

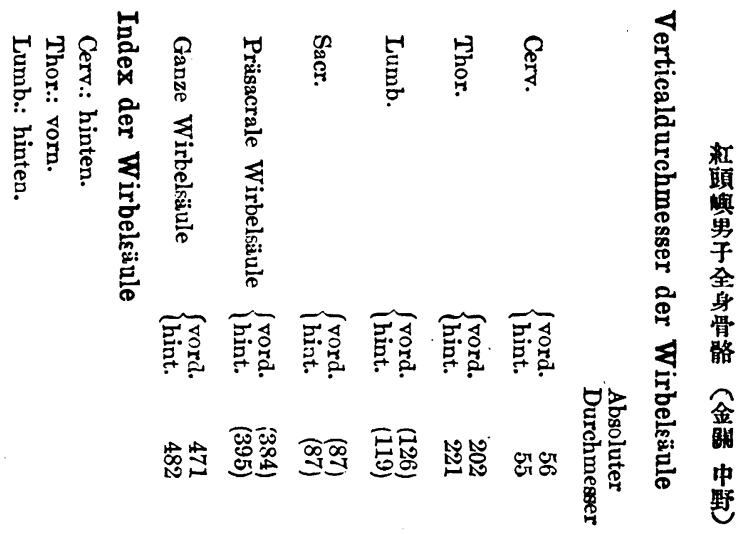

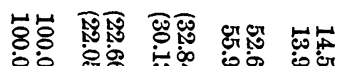

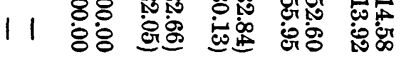

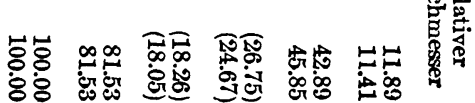

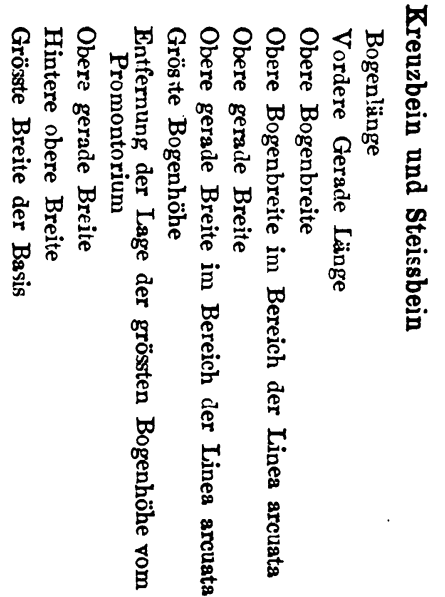

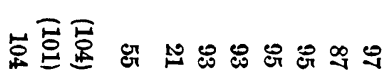
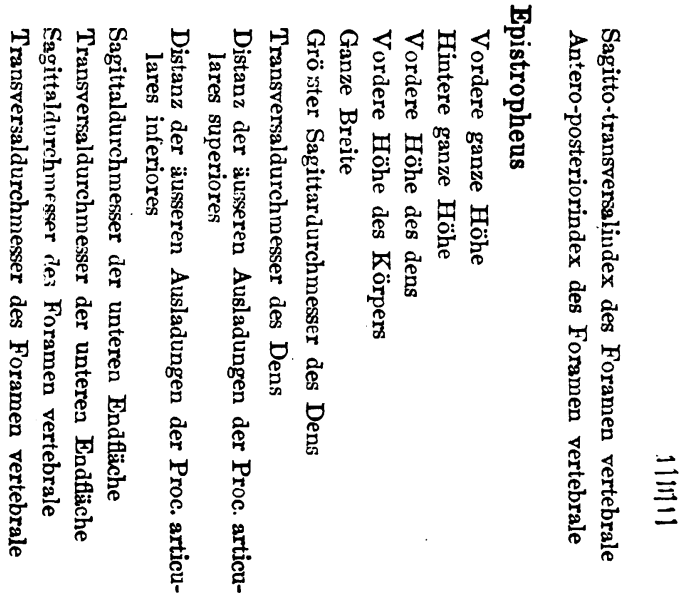

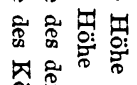

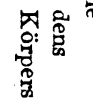

四然骂 总

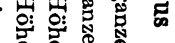

究.

范营

密

范

苏

옹 웅

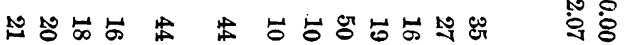




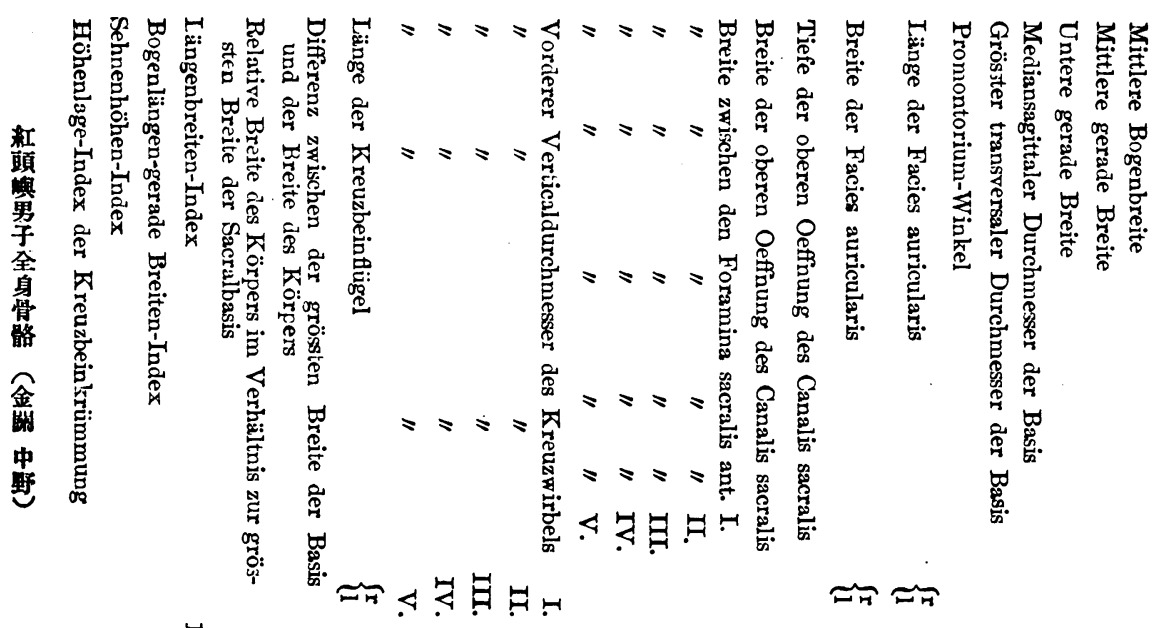

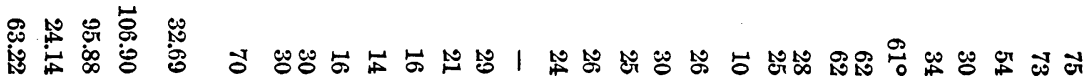
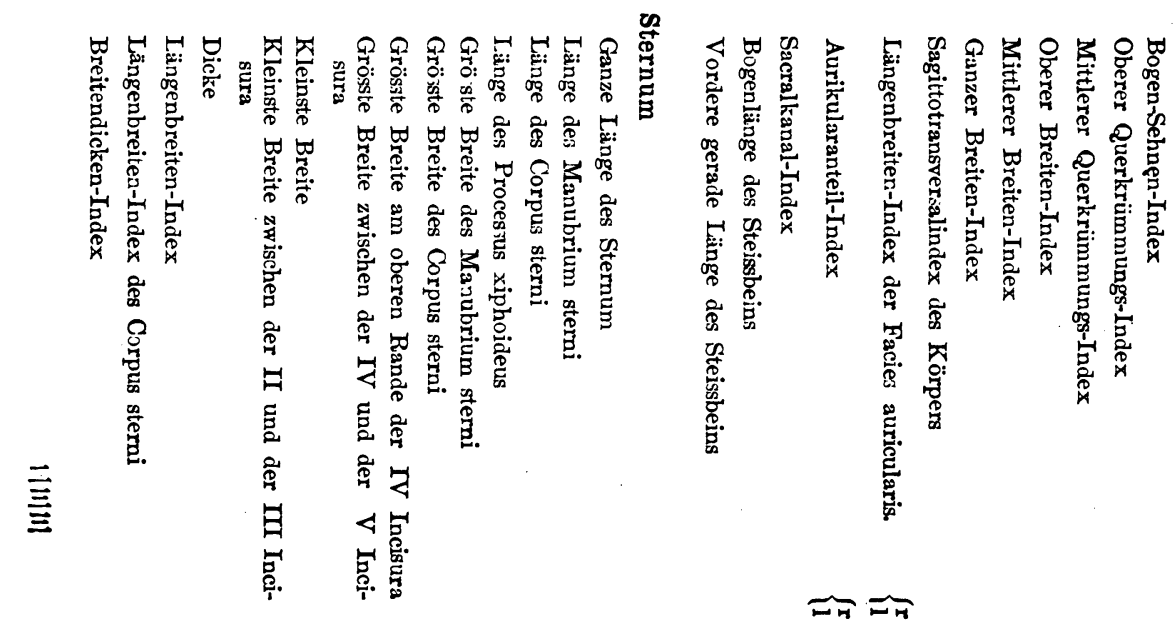

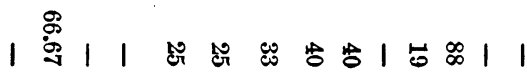

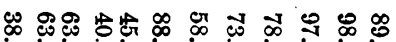

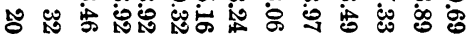




\section{人類學雜绻 45.6}

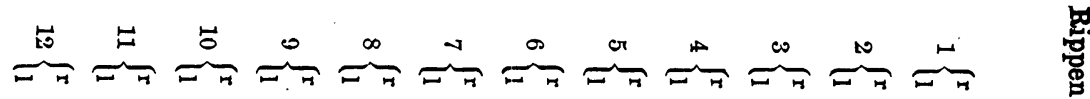

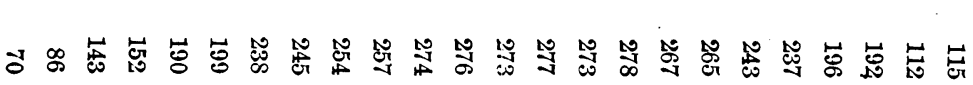

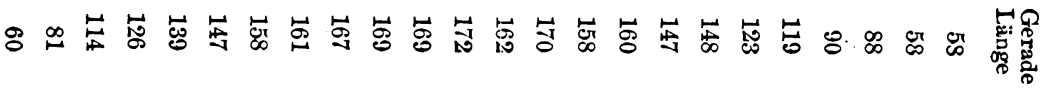

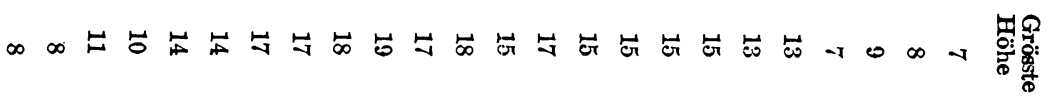

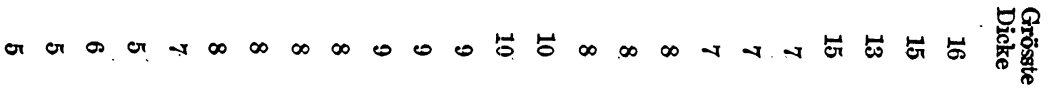

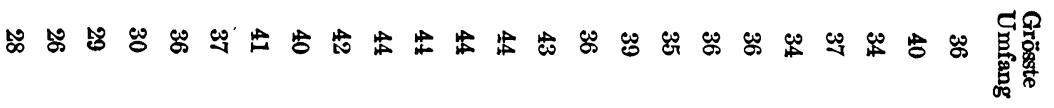

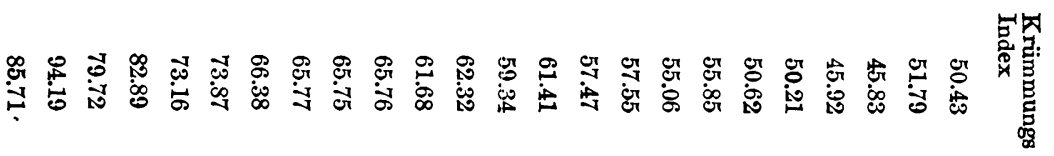

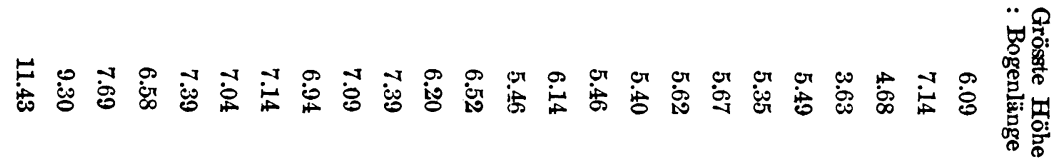

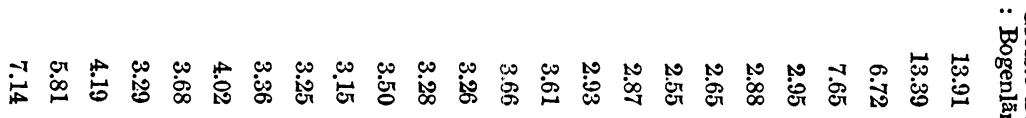

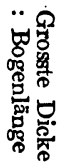

要

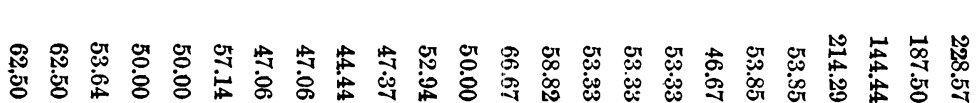

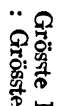

解 


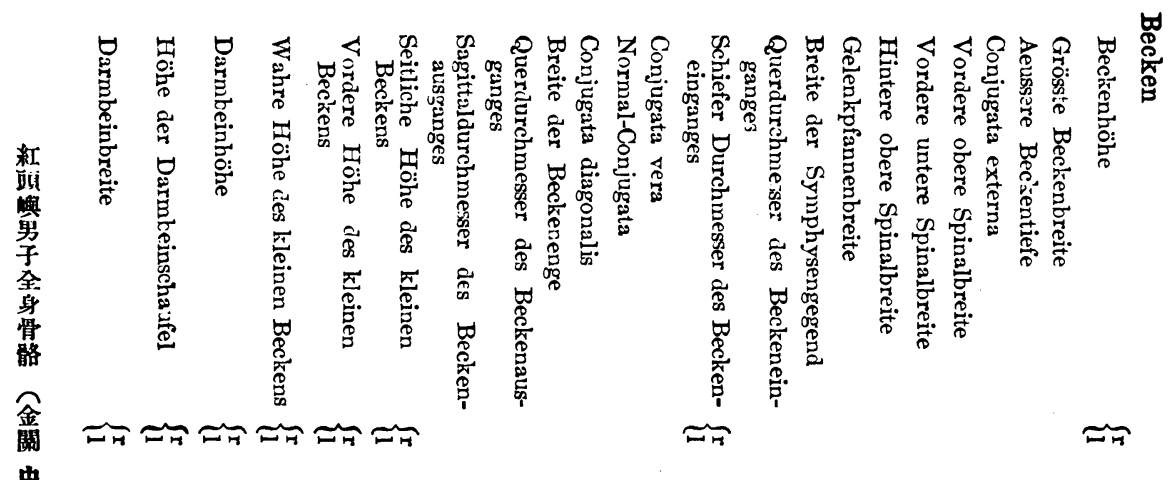

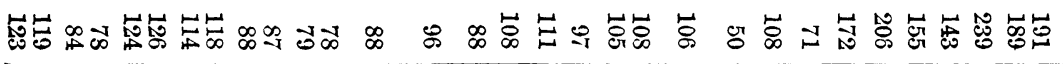

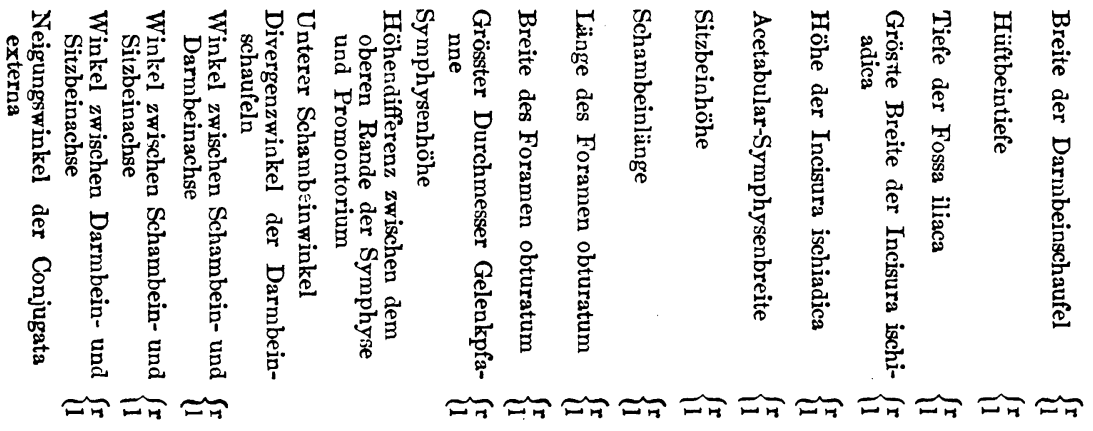

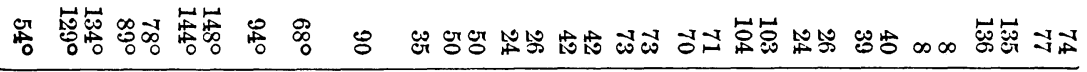

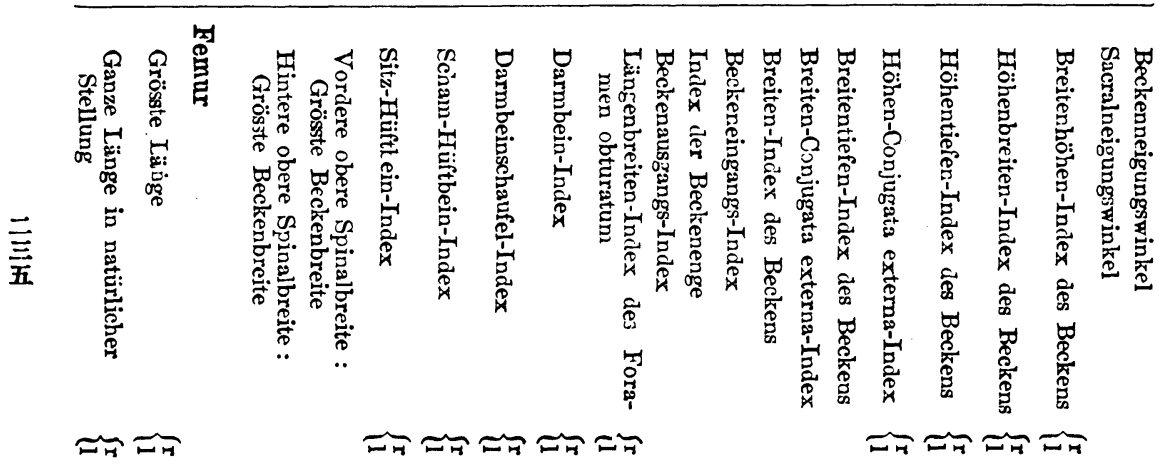

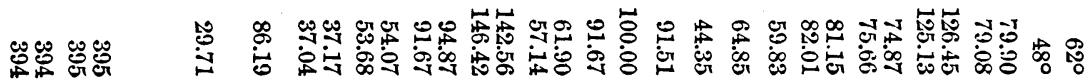




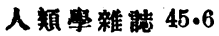
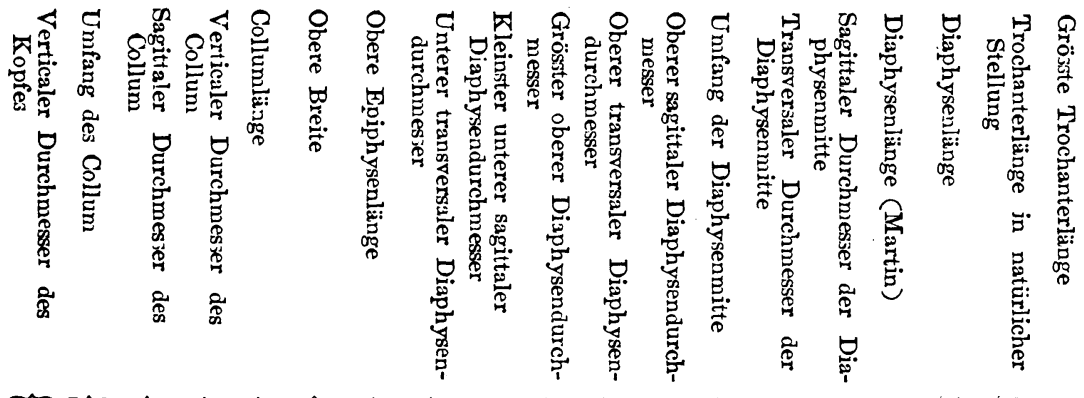

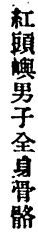

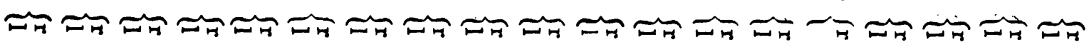
銅

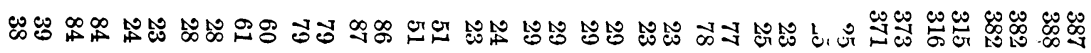

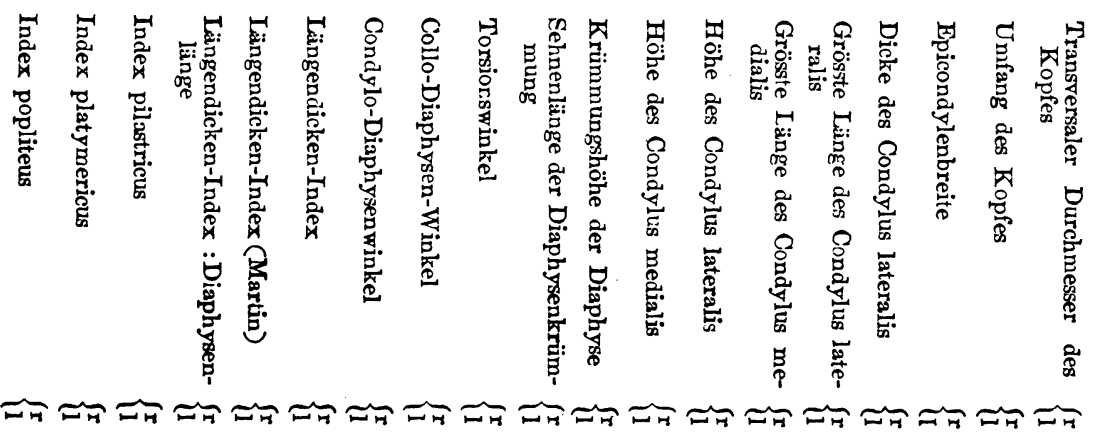

出出

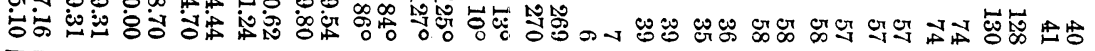
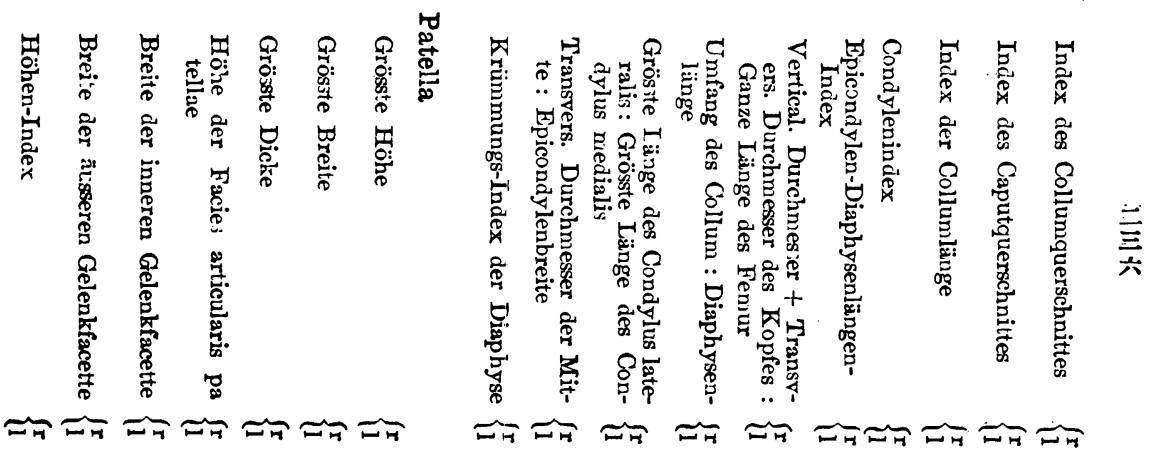

erer

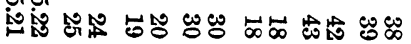

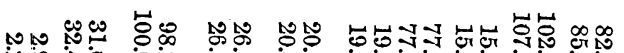

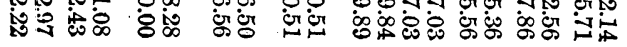


昭和 5 年 6 月

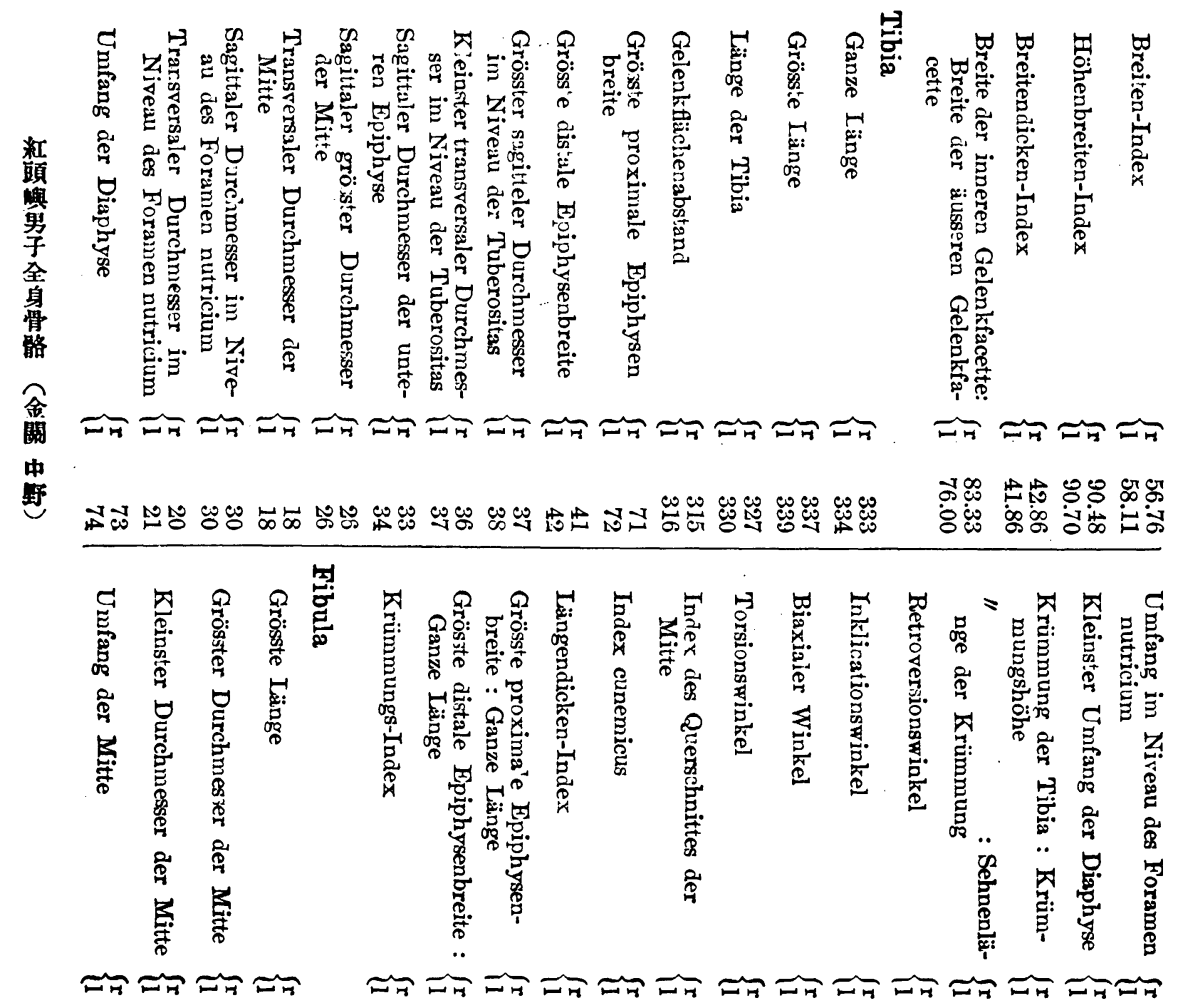

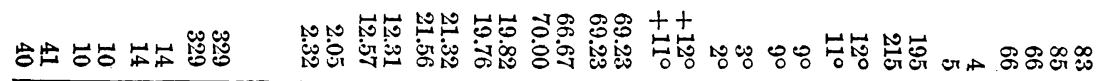
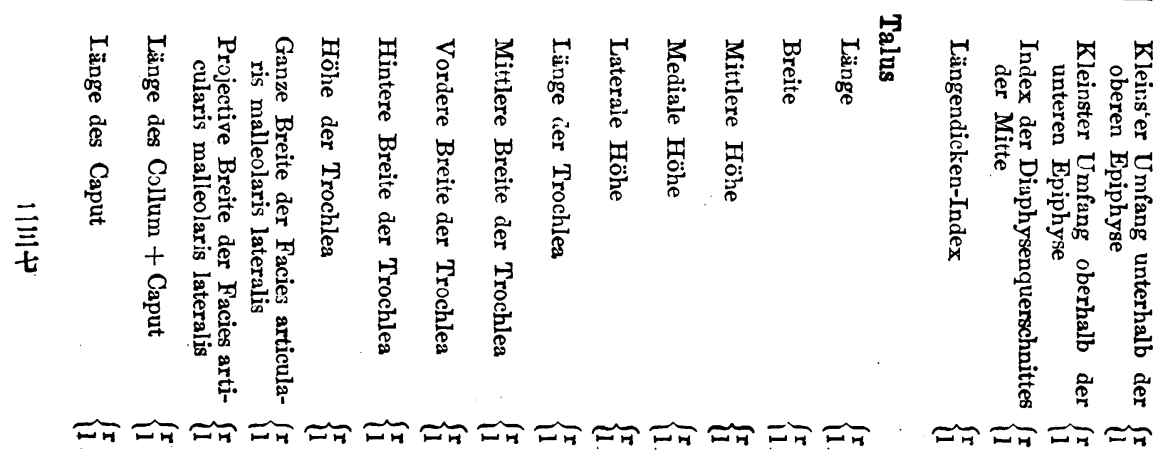

ง 


\section{人類祭雜譡 $45 \cdot 6$}
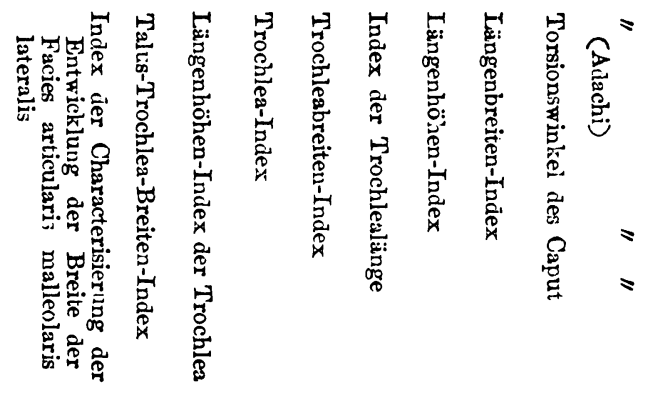

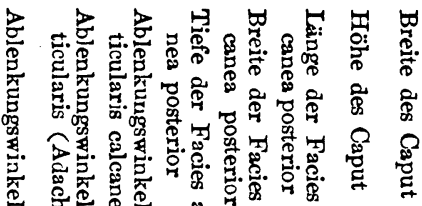

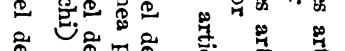

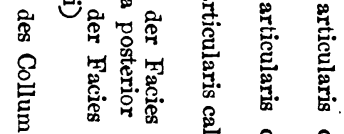

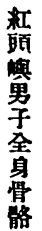

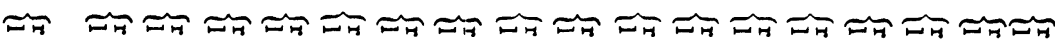

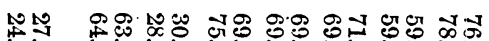

惫

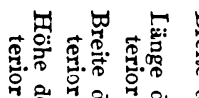

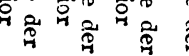

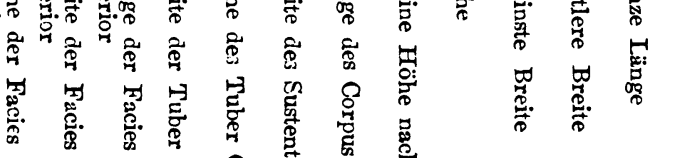

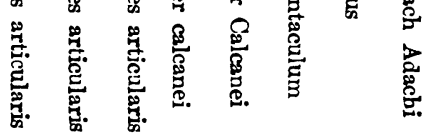

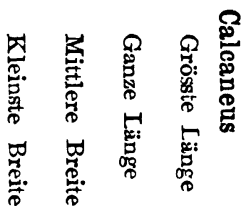

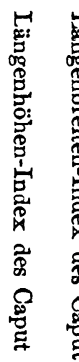

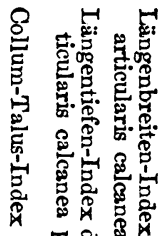

¿ : : :

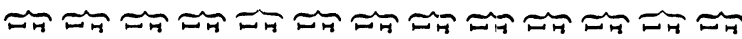

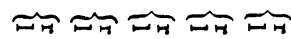

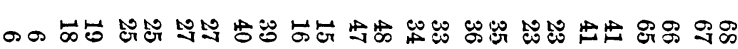

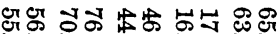
용 붕

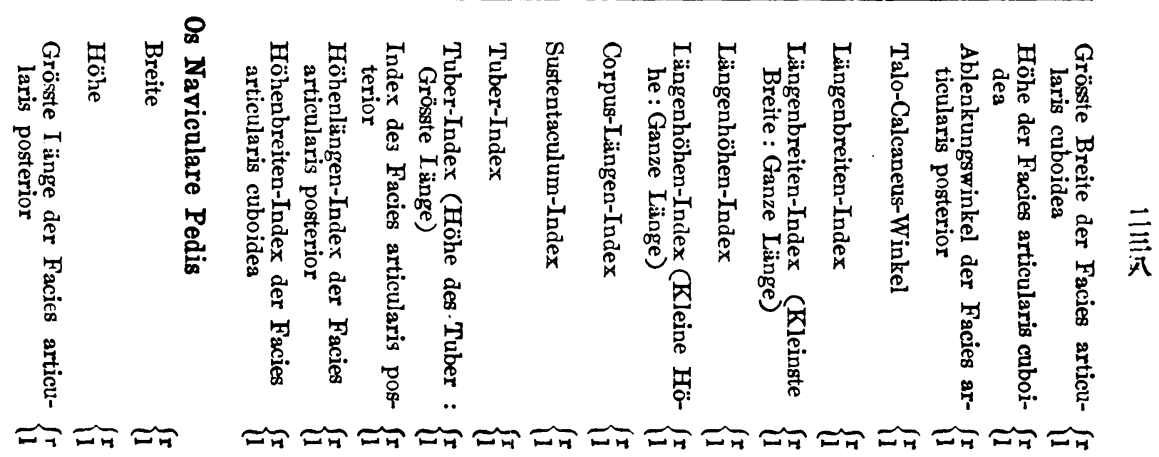

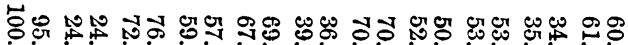

खN 


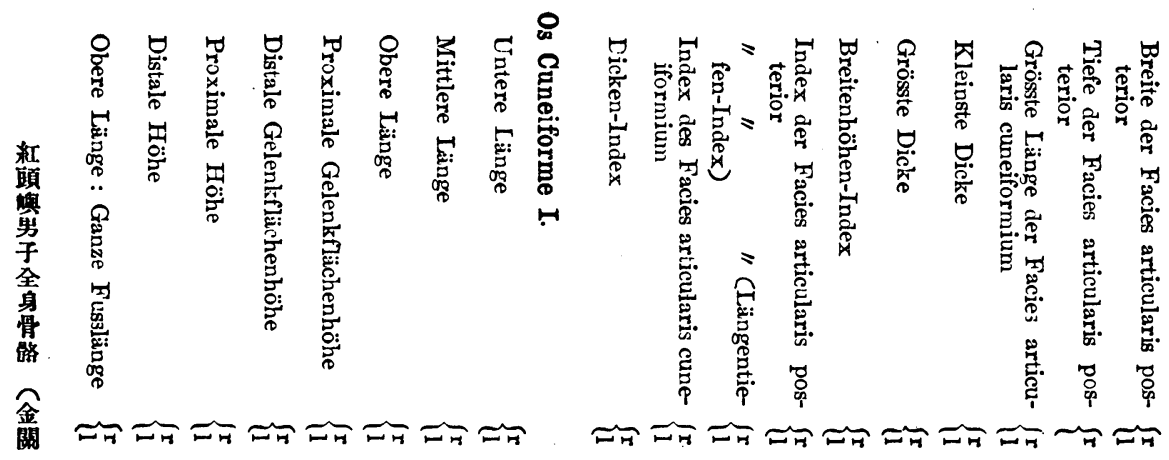

中 野它

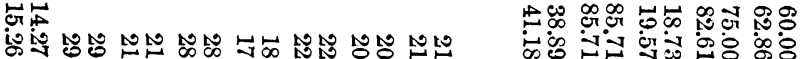
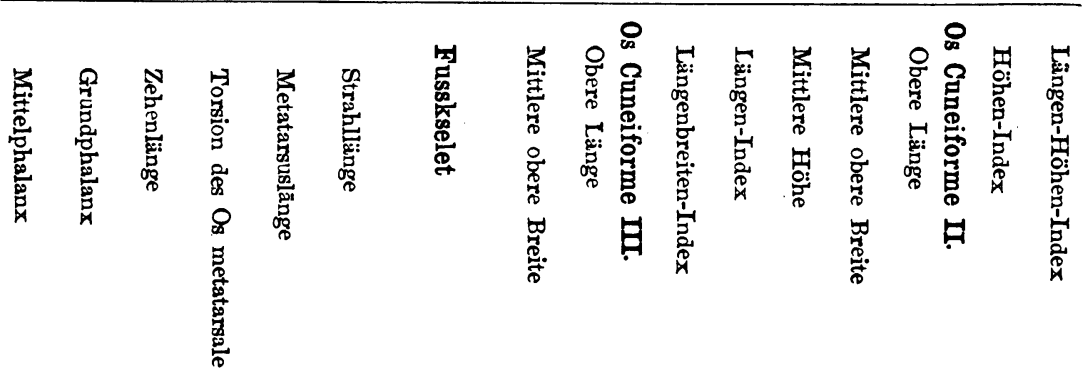

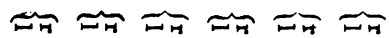

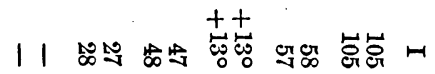

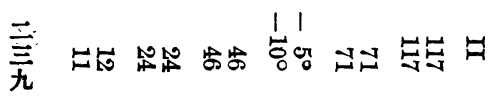

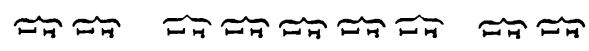

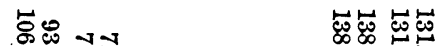
战 ชำ

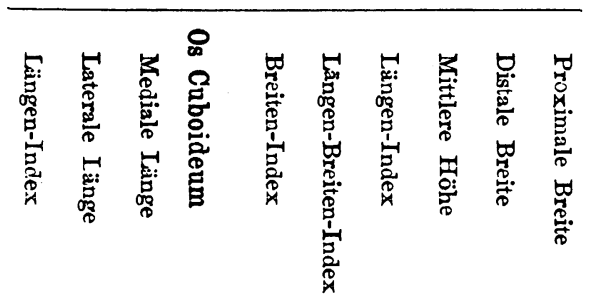

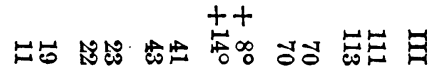

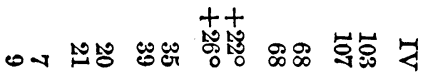

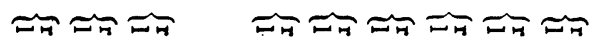

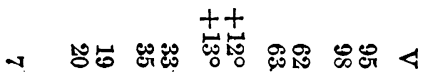
당 잉 


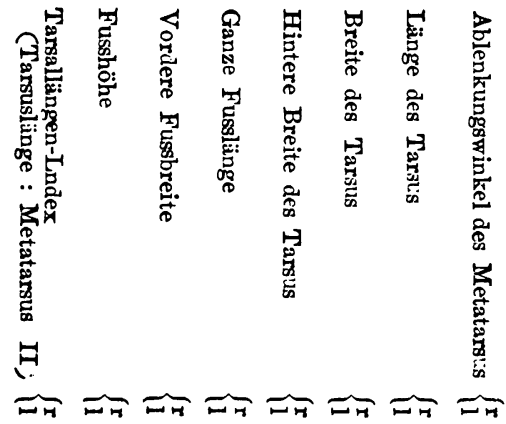

버ㄱㅝㅓㄱ

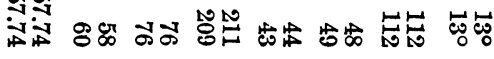

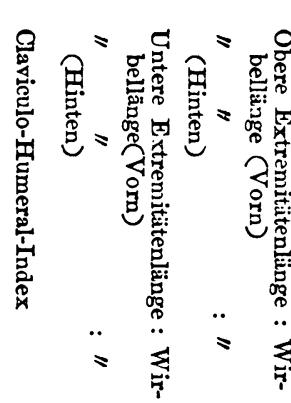

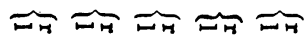

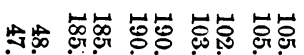
\%벙 붕 $\widetilde{\pi} \approx$
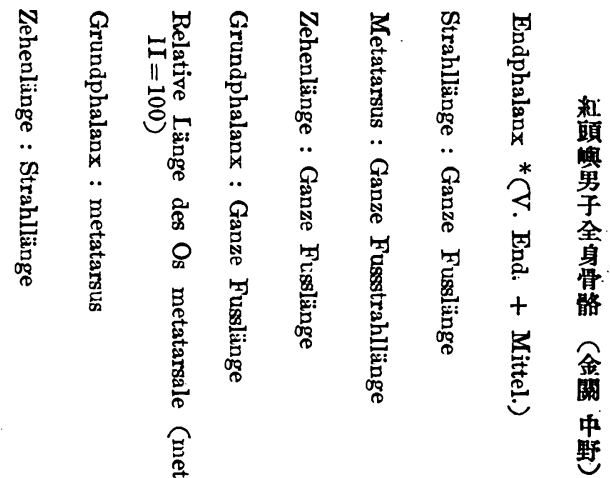

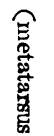

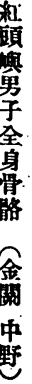

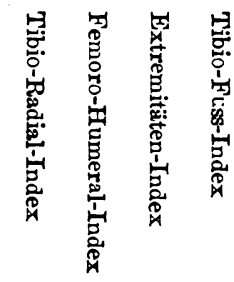

朂

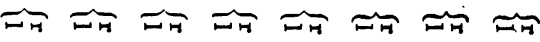

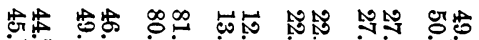

जٓ

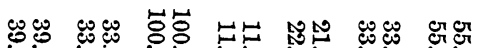

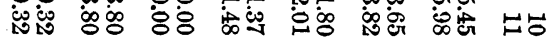

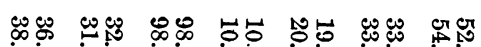

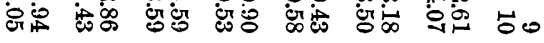

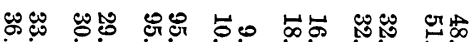

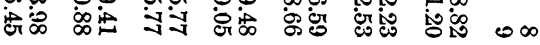
幽崖峞

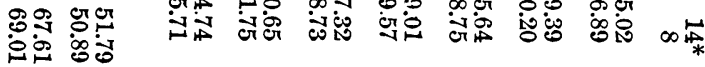

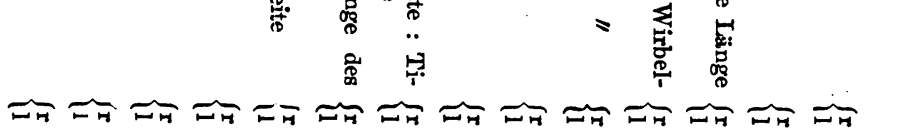

요 可 
昭和 5 年 6 月

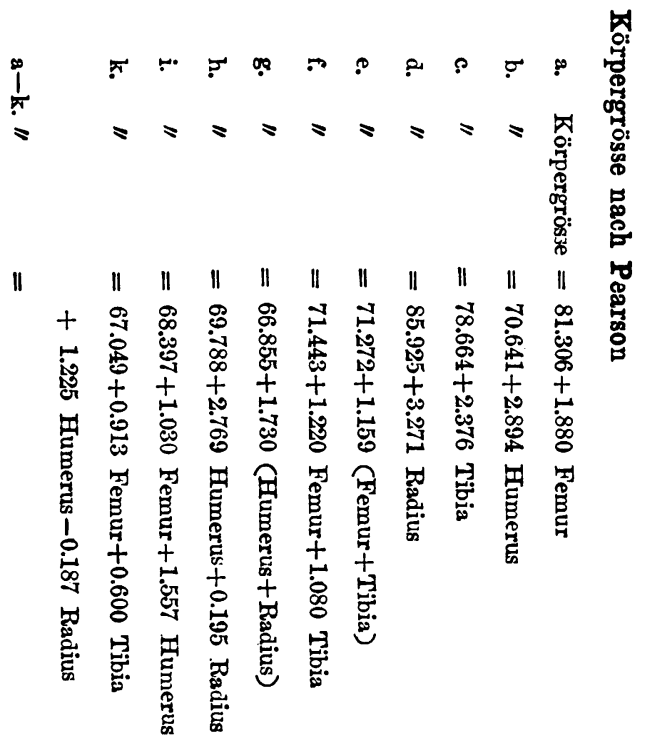

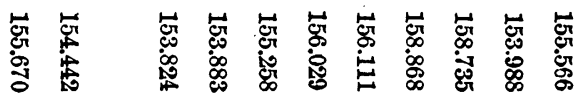

西 